\title{
Jamesiella scotica new to North America from USA, Alaska
}

\author{
Tor Tønsberg \\ Department of Natural History, University Museum, University of Bergen, N-5020 Bergen, Norway \\ Email: tor.tonsberg@uib.no
}

\begin{abstract}
Jamesiella scotica is reported new to North America from Kenai Fjords National Park in Alaska. It was found on live and moribund leaves of the bryophyte Paraleucobryum longifolium on sea-shore rocks just above high tide line.
\end{abstract}

Keywords: lichen, Kenai Fjords National Park, new species, sea shore

\section{INTRODUCTION}

During field work in Kenai Fjords National Park, SW of Anchorage in Alaska, U.S.A, in July 2015, I collected a specimen of Massalongia carnosa (Dicks.) Körb. Later, when I was processing the specimen, I realized that the Massalongia was associated with a specimen of Jamesiella scotica (P. James) Lücking, Sérus. \& Vězda. As this species appears to be new to North America (see Esslinger 2015) it is further commented on below.

Jamesiella Lücking, Sérus. \& Vězda is a recently described genus of four species (Lücking et al. 2005, 2006). Most of the species were previously assigned to Gyalideopsis Vězda (James 1975, Vězda \& Hafellner 1988). Jamesiella differs from Gyalideopsis by the isidiiform hyphophores which have internal conidia and function as diaspores (Lücking et al. 2005, 2009). A key to the species of Jamesiella is provided by Lücking et al. (2006, page 150). Esslinger (2015) in The North American checklist for lichens, lists one species, J. anastomosans (P. James \& Vězda) Lücking, Sérus. \& Vězda. Jamesiella anastomosans and $J$. scotica are easy to separate. Jamesiella anastomosans has spine-like, often almost colourless and translucent hyphophores, usually 8-spored asci and is corticolous, whereas $J$. scotica has pale brown to reddish brown, suglobose (when young) to peg-like and apically flattended hyphophores, 2-spored asci and is muscicolous. For complete descriptions, see James (1975) and Lücking et al. (2005, 2009).

\section{RESULTS}

The material of Jamesiella scotica from Alaska (Fig. 1) comprises one sterile specimen with numerous hyphophores on moribund (mainly) and live bryophyte leaves of Paraleucobryum longifolium (Hedw.) Loeske on a thin layer of humus. It was collected from the upper, flat part of a low boulder on sea-shore granitic rock just between the upper tide line and a fringe of Alnus viridis. Juvenile hyphophores were more or less colourless and translucent, whereas welldeveloped ones were reddish brown and up to $0.12 \mathrm{~mm}$ wide and tall. The inner part supported some scattered and clustered algal cells. Close associates of lichens were Massalongia carnosa, Cladonia sp. (squamules), and Arthrorhaphis aeruginosa R. Sant. \& Tønsberg (sparse).

According to Lücking et al. (2009), Jamesiella scotica is a rare species occurring on decomposing liverworts and mosses on base rich mountain rock and soil. The specimen from Alaska grew on granitic rock in maritime situation near the sea-level. It might be that spray from the sea was compensating for the lack of base rich rock at the site and/or that the substrate specificity is weaker than previously supposed.

Jamesiella scotica was previously regarded as endemic to the British Isles (Lücking et al. 2009). It is here reported new to North America. With this new locality, the species shows a northwestern Europe to northwestern North America disjunct distribution.

Specimen examined. U.S.A., Alaska, Kenai Peninsula Co., Kenai Fjords National Park, off Aialik Bay, NE end of Coleman Bay, $59.88069^{\circ} \mathrm{N} 149.61673^{\circ} \mathrm{W}$ (WGS84), alt. 1-5 m, overgrowing moribund (mainly) and live leaves of Paraleucobryum longifolium on sea-shore granitic boulder just above upper tide line, 9 July 2015, Tønsberg 45475 (BG).

Specimen examined for comparison. England, Cumbria, above Brown Cove, Helvellyn, N. facing cliffs, 1991, O.L. Gilbert (BM 552713). 


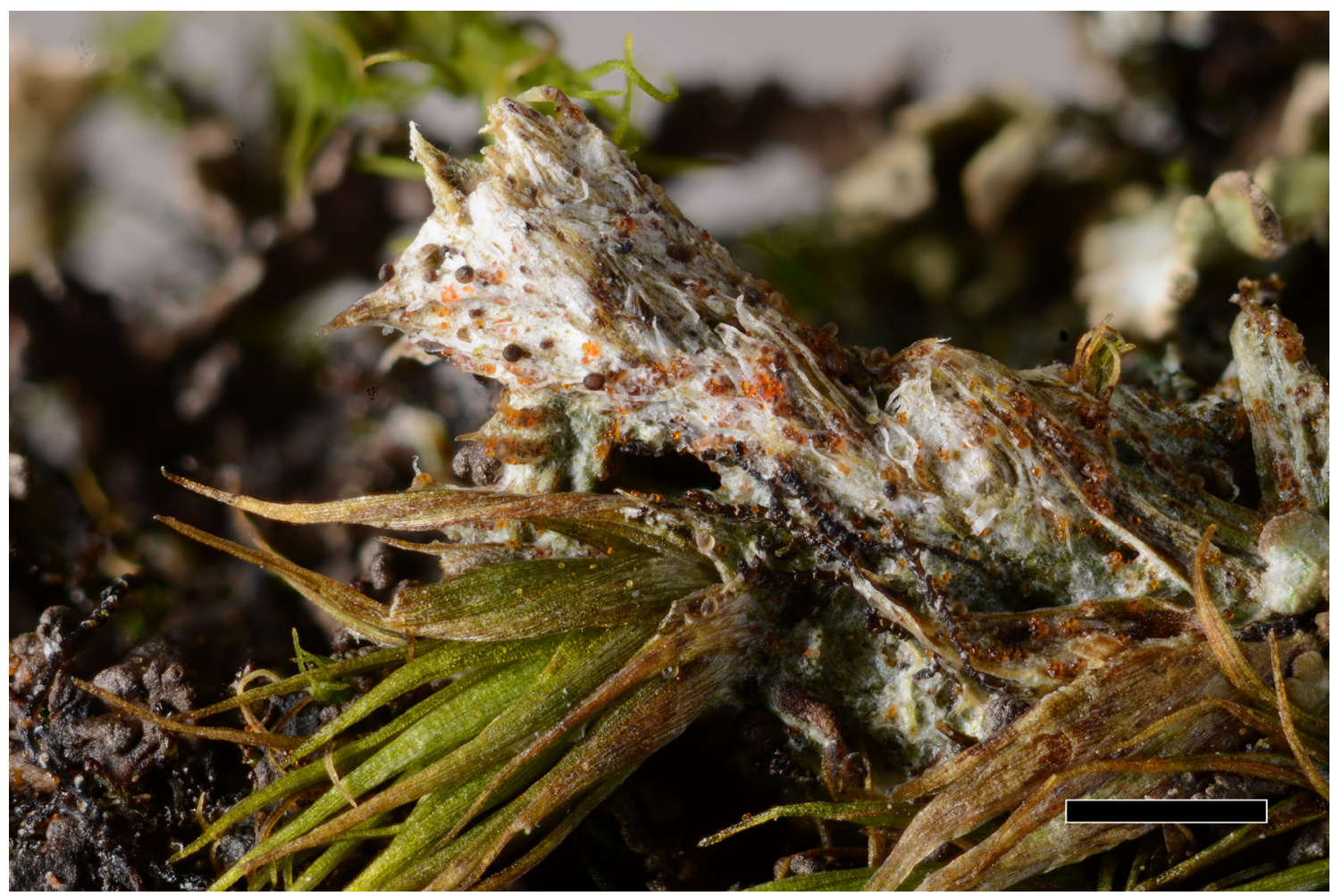

Fig. 1. Jamesiella scotica, Tønsberg 45475, from Alaska (photo E. Timdal 2016.). Scale: $1 \mathrm{~mm}$.

\section{ACKNOWLEDGEMENTS}

I thank Bruce McCune, Oregon State University, for the invitation to do lichenological field work in Kenai Fjords National Park in 2015 and for comments on the manuscript; the National Park Service (NPS), Southwest Alaska Network, Anchorage, for funding; Amy Miller and James Walton (both NPS) for project coordination and for organizing and executing field logistics; the curator at the herbarium BM for loan of the herbarium specimen; Einar Timdal, University of Oslo, for the photo; and Bernard Goffinet, University of Connecticut, for the identification of the bryophyte.

\section{REFERENCES}

Esslinger, T. L. 2015. A cumulative checklist for the lichen-forming, lichenicolous and allied fungi of the continental United States and Canada. North Dakota State University: http:/ /www.ndsu.edu/ pubweb/ esslinge/chcklst/chcklst7.htm [first posted 01.12.1997, most recent version (\#20) 19.04.2015].
James, P. W. 1975. The genus Gyalideopsis Vězda in Britain. Lichenologist 7(2): 155-161. http:// dx.doi.org/10.1017/S0024282975000217

Lücking, R., Aptroot, A., Umaña, L., Chaves, J. L., Sipman, H. J. M. \& Nelsen, M. P. 2006. A first assessment of the Ticolichen biodiversity inventory in Costa Rica: the genus Gyalideopsis and its segregates (Ostropales: Gomphillaceae), with a world-wide key and name status checklist. Lichenologist 38(2): 131-160. http://dx.doi. org/ 10.1017/S0024282905005657

Lücking, R., Sérusiaux, E. \& Vězda, A. 2005. Phylogeny and systematics of the lichen family Gomphillaceae (Ostropales) inferred from cladistic analysis of phenotype data. Lichenologist 37(2): 123-170. http:/ /dx.doi.org/10.1017/S0024282905014660

Lücking, R., Sérusiaux, E. \& Vězda, A. 2009. Jamesiella Lücking, Sérusiaux \& Vězda (2005). In: C. W. Smith, A. Aptroot, B. J. Coppins, A. Fletcher, O. L. Gilbert, P. W. James \& P. A. Wolseley (eds). The lichens of Great Britain and Ireland. Pp. 447-448.

Vězda, A. \& J. Hafellner. 1988. Zwei neue Gyalideopsis-Arten aus den Regenwaldern Australiens: $G$. perlucida und G. rogersii (lichenisierte Ascomycetes, Gomphillaceae). Preslia [Praha] 60: 239-243. 